\title{
CMAJ instruction of authors in the 20th century: from literary style to Vancouver style
}

$\mathrm{W}$ hen $C M A J$ editor Andrew Macphail declared in the journal's inaugural issue "There is probably more bad writing in medical journals than in any other kind of periodicals," he set the tone for its first 50 years. ${ }^{1}$ Macphail and his three successors, A.D. Blackader (editor 1919-1929), A.G. Nicholls (editor 1930-1942) and H.E. MacDermot (editor 1942-1955), all treated medical writing as composition - essentially a literary activity. During $C M A J$ 's next 50 years, however, the biomedical research community would change everyone's views of writing for publication, as the byline on a single article expanded from sole authors to many contributors from different scientific fields. This change in turn forced the gaze of $C M A J$ editors to shift from an author's literary style to questions about authorship itself. By the 1980s, CMAJ was participating in a global effort to develop standards of medical publication through the International Committee of Medical Journal Editors (ICMJE). ${ }^{2}$

\section{The instruction of writers}

In 1911, Macphail so lamented authors' use of medical jargon and "flamboyant" language that he arrived at the "melancholy conclusion" that good writing had filled medical journals in the past. ${ }^{1}$ His view reflected his own prodigious output as reporter; editor of the Montreal Medical Journal since 1903; editor of a literary journal, University Magazine, from 1907 to 1912; and author of essays, poems and novels. ${ }^{3}$ After his war service in France, for which he was knighted, he compiled the official history of medical services in World War I. The first professor of the history of medicine at McGill University, Macphail embodied our modern-day concept of medical humanities. His editorials invited both good

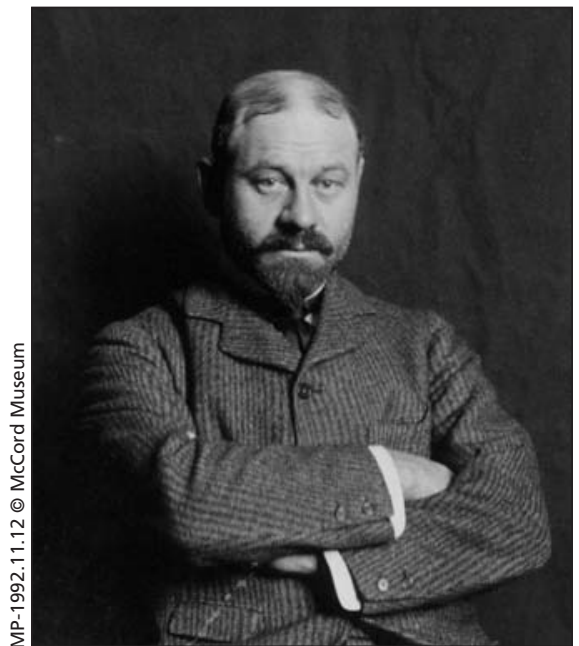

This undated photograph of Dr. Andrew Macphail was probably taken around 1907 when he was editor of Montreal Medical Journal and a member of the Pen and Pencil Club of Montreal (with other members such as Stephen Leacock and Dr. John McCrae). One of Canada's most influential intellectuals at the time, Macphail went on to become CMAJ's first editor.

writing and submissions from everyone: "The Journal is not a great sheet which comes down from heaven: it is an instrument of the profession to be used by all in the interests of all."

Macphail's successor, A.D. Blackader - like Macphail, initially an Arts graduate - took over the editorship at the age of 72 . He became recognized for his "scrupulous care in editing each individual article, jealous of its literary quality, merciless in tracking down faulty references and ill-chosen words, and [for] his querulous, half humourous letters to contributors on the sin of careless writing." ${ }^{5}$ Recalled H.E. MacDermot, "Not infrequently, he would rewrite the article and even add material to it. In my long association with him I would come across instances of such rehabilitation, in which the authors would accept the end product with complacency."
Along with their counterparts elsewhere, CMAJ editors maintained for decades that good medical writing could be taught through editorials. In 1937, the third CMAJ editor, A.G. Nicholls, thus reacted to a supplement published on writing for The Lancet with his own rules to make the "editors' lot a happier one." Some may resonate today: "The word 'case' is often used as synonymous with 'patient', man, woman, or child. A 'case' is impersonal; it is an account of a 'patient's' ailment, not a person. You cannot operate on a case." Such instruction aimed also to demystify the medical journal and the editor's role, as in a series of 10 editorials in 1965 that portrayed the editor as Everyman - "a cipher" to physicians and a "medico-literary referee" - who championed the cause of the reader. ${ }^{8}$

Over several decades with CMAJ, H.E. MacDermot followed Macphail's lead to remark on authors' "carelessness of expression": "The more one sees of medical writing the more surprised one is at the incoherence of the average writer."',10 Macphail had noted a common complaint that the "pen and ink men" monopolize medical journals over "those who work but do not write." ${ }^{\prime}$ But MacDermot felt the problem lay in lack of leisure for physicians to digest their "extra-medical reading" to improve the quality of their medical writing: "One need not copy an author's style, but his principles are always within reach." $\mathrm{He}$, like Macphail, valued medicine and the humanities: he honed his own literary skills by writing articles and books on the history of the Canadian medical profession. In 1961, MacDermot still focused on literary form when he observed that medical writing was not as good as 50 years before - when CMAJ began, under Macphail as editor. ${ }^{6}$ For 50 years, $C M A J$ editorials thus appear 
mainly to reinforce the many "consciousness-raising articles" about medical writing and its decline that routinely appeared in medical journals. ${ }^{12}$

Macphail taught an evening class on writing and editing for medical students at McGill no doubt because he blamed younger writers for a decline in journal quality. (MacDermot was one of his students.) $C M A J$ editors promoted such classroom instruction ${ }^{13}$ and taught popular courses themselves through the 1970s. ${ }^{14}$ More than clear expression was at stake, for they believed that reticence and inexperience discouraged physicians from writing up their experiences. Editors calculated the cost of "this expositional palsy" in 1969. Of 100 papers in a (tongue-in-cheek) new specialty of omphalology over 15 years, they posited, two-thirds were written by one of its 26 practitioners; the other 25 specialists wrote nothing or only two to three papers each. Pointing to examples of improved output after assistance, they concluded that writing instruction was necessary. ${ }^{15}$ Editors also complained about the "malignant proliferation" of medical literature while, paradoxically, they encouraged more submissions through concise writing: "one message — one publication."'16

\section{The instruction of authors}

In 1978, CMAJ editors became involved in a form of instruction that would change not only their own journal, but hundreds of medical journals around the world. As far back as 1928, medical scientist A.B. Macallum worried about the trend of splitting one study into many articles and wondered about establishing a League of Nations committee "to suggest a code of ethics which will impose a severe circumspection regarding publication in science." ${ }^{17}$ Fifty years later, from a meeting in Vancouver with $C M A J$ as a founding member, ICMJE embarked on just such an ambitious campaign to improve and standardize publication in medicine. The initially titled Vancouver Group's work began as a style guide for manuscript format, which became known as the Vancouver style. Its Uniform Requirements for Manuscripts Submitted to Biomedical Journals ${ }^{2}$ were published in member journals and eventually adopted by several hundred medical journals. They continually undergo revisions to keep pace with activities in medical publishing.

The ICMJE and related groups helped to stimulate investigation into their own journal activities — raising awareness in many ways - though they have been widely criticized and not as influential as member editors had hoped. The most controversial problems they attempted to tackle remain those surrounding authorship and its definition. As biomedical research grew, so did the number of names in an article byline, leading to journal policies against guest or ghost authors. However, editors' views still implicitly emphasized a longstanding literary concept of individual authorship "at the expense of other contributions to the knowledge-making process." ${ }^{\prime 18} C M A J$ editors joined their international counterparts in writing about the Uniform Requirements, but editorials by Peter Morgan (editor 1981-1987), gathered in book form as an insider's guide, reveal the beginnings of a shift in this thinking. Morgan cautioned that although an approach did exist to "writing with style about the sciences through writing skills learned in the humanities," there is a point where scientific style and literary style part ways: the need of the reader. ${ }^{19}$ Moreover, in contrast to his early $C M A J$ predecessors, he argued that medical writing was continually improving thanks to advances in computer technology, professional researchers, organization of editors and standardization of manuscript style. ${ }^{20}$

\section{Conclusion}

As this brief overview indicates, early $C M A J$ editors used editorials and classes to instruct writers in developing acceptable manuscripts. Their focus for 50 years was on literary style, and they were routinely praised for their own literary ability as editors. ${ }^{5,6}$ After the creation of the ICMJE guidelines, however, editorial practices such as those of A.D. Blackader would run afoul of the requirement that authors take public responsibility for their article. In particular, Blackader not only added material to a manuscript, but he accepted without question the byline on CMAJ's most famous article (the 1922 report that pancreatic extract reduced blood sugar levels in a diabetic patient). ${ }^{21}$

Where early editors worried about the mechanics of writing within a manuscript, larger developments through ICMJE meant that later CMAJ editors worried about authorship, an abstract concept involving credit and responsibility for a manuscript. In other words, editors shifted their gaze from the page to the author of the page.

\section{Jennifer J. Connor PhD}

Medical Humanities

Discipline of Psychiatry

Faculty of Medicine

Memorial University of Newfoundland St. John's, NL

This article has been peer reviewed.

\section{References}

1. Style in medical writing. Can Med Assoc J 1911;1: 70-3.

2. International Committee of Medical Journal Editors. Uniform requirements for manuscripts submitted to biomedical journals. The Committee; 2010. Available: www.icmje.org/urm_main.html (accessed 2012 May 4).

3. Robertson IR. Sir Andrew Macphail: the life and legacy of a Canadian man of letters. Montréal (QC): McGill-Queen's University Press; 2008

4. The journal and the profession. Can Med Assoc J 1911;1:263-4.

5. Martin CF. In obituary discussion: Alexander Dougall Blackader, M.A., M.D., LL.D., M.R.C.S., F.R.C.P.(C.). Can Med Assoc J 1932;26:522.

6. MacDermot HE. The fiftieth anniversary of the association journal. Can Med Assoc J 1961;84:1-5.

7. AGN [Nicholls AG]. On writing for medical journals. Can Med Assoc J 1937;37:73-4.

8. Medical journalism. IX: What the medical editor does. Can Med Assoc J 1965;93:82-3.

9. Macdermot HE. The editing of medical papers Can Med Assoc J 1942;47:263-5.

10. HEM [MacDermot HE]. Reflections on medical writing. Can Med Assoc J 1928;19:708.

11. HEM [MacDermot HE]. Medicine and the humanities. Can Med Assoc J 1938;39:383-4.

12. Segal JZ. Health and the rhetoric of medicine. Carbondale (IL): Southern Illinois University Press; 2005. p. 131.

13. Godden JO. Mind to mind: persuasion in medical writing. Can Med Assoc J 1967;96:958-64.

14. Sherrington A. Seventy years of editorial excellence. Can Med Assoc J 1981;125:85-93.

15. Teaching scientific writing. Can Med Assoc J 1969; 101:297-9.

16. Medical journalism. VIII: Boiling it down. Can Med Assoc J 1965;92:1230-1.

17. Macallum AB. Of the making of books there is no end. Can Med Assoc J 1928;19:80-1.

18. Biagioli M. The instability of authorship: credit and responsibility in contemporary biomedicine. FASEB J 1998;12:3-16.

19. Morgan P. An insider's guide for medical authors and editors. Philadelphia (PA): ISI Press; 1986. p. 27-8.

20. Morgan PP. Why scientific communications are improving. Can Med Assoc J 1984;130:8.

21. Hoey J. Who wrote this paper anyway?: The new Vancouver Group statement refines the definition of authorship. CMAJ 2000;163:716-7.

CMAJ 2013. DOI:10.1503/cmaj.111430 